\title{
The impact of COVID-19 on A Level students in England
}

Preliminary Report of Findings

Kalwant Bhopal and Martin Myers

August 2020 


\section{The impact of COVID-19 on A level students in England}

\section{Introduction}

The global outbreak of the COVID-19 virus created new and challenging circumstances for schools, colleges and universities in England. On Friday 20 $0^{\text {th }}$ March 2020 the Department for Education (DfE) announced the closure of all schools and colleges with only a very restricted provision made for the children of 'key workers' unable to access childcare and vulnerable children (DfE, 2020a). This was immediately followed by a further announcement confirming the cancellation of the 2020 'summer exam series, including A Levels, GCSEs and other qualifications, and all primary assessments' (DfE, 2020b:1) ${ }^{1}$. The DfE in conjunction with The Office of Qualifications and Examinations Regulation (OFQUAL) which regulates qualifications, exams and assessments in England decided that students who were due to sit their GCSE and A Level exams would be awarded a 'calculated grade' (DfE, 2020c: 1).

A Level grades have a significant impact on outcomes for pupils leaving school including access to the employment market, apprenticeships and university places. Consequently these examinations affect all aspects of future life chances, access to the labour market and social mobility (Bhopal, Myers and Pitkin, 2020). The project specifically focussed on the impact of such measures on A Level students and to explore their experiences of school closures and the cancellation of examinations. The main aims of the study were:

1. To examine the impact (mental and academic) of predicted grades on A Level students;

2. To explore support systems in place for such students; and,

3. To analyse differences by race, class, gender and school type.

\footnotetext{
1 'A Levels' (Advanced Levels) are examinations generally taken by students in England aged 18 at the end of their secondary education. GCSEs (General Certificate of Secondary Education) are exams generally taken at age 16 .
} 


\section{Background}

Previous research has found that A Level predictions for students in the UK are inaccurate (Everett and Papageourgiou, 2011; UCAS, 2016) with only 16\% of grades predicted by teachers being reflected in actual grades achieved (Murphy and Wyness, 2020). Inaccurate predictions of A Level grades are particularly problematic for students intending to progress to university. Students who are under-predicted are likely to apply for less prestigious institutions; whilst, those who are over-predicted are more likely to apply for more prestigious institutions but then not secure their preferred choice. Everett and Papageourgiou (2011) found that Black applicants had the lowest predicted A Level grade accuracy compared to white students who had the highest. Anders et al (2020) have found that high achieving students in comprehensive schools are more likely to be under predicted compared to those at grammar or independent schools. The Sutton Trust's analysis of students from less affluent families noted the greater impact inaccurate predictions of grades had on their university choices often leading, 'many disadvantaged students to make sub-optimal decisions when choosing their universities' (Wyness 2017: 3). Grades for students from ethnic minorities are often over-predicted by teachers; the inaccuracy of such predictions similarly results in poorer outcomes when students do not achieve the grades they require for their first choice university (Murphy and Wyness, 2020).

At the time of the initial announcement of calculated grades the full detail of the process OFQUAL would use to award grades was not published in order to avoid schools 'gaming' results; however, three key elements of the process were outlined (OFQUAL 2020a). Firstly schools and colleges would submit 'Centre Assessed Grades' for individual pupils to OFQUAL. Secondly teachers would submit a rank order of where students' results were expected to fall in relation to each other. Finally OFQUAL would use the data submitted by schools and standardise the outcomes to ensure there was not a significant element of grade inflation. This standardisation process became associated with OFQUAL's use of an 'algorithm' to calculate the grades announced to students on A-Level results day, Thursday 13 August 2020.

Concerns about the award of grades within the extraordinary circumstances of school closures and cancellation of examinations were widely identified before results day. Initial concerns were raised that students from marginalised, minority and working class 
backgrounds were likely to be disadvantaged by the process; whilst those from middle class, wealthy backgrounds and those attending independent fee paying schools were likely to benefit (Weale and Batty, 2020). The House of Commons (HoC) Education Committee raised similar concerns and argued that OFQUAL should address emergent inequalities within the standardisation process and that 'Ofqual must be completely transparent about its standardisation model and publish the model immediately to allow time for scrutiny' (HoC, 2020: 4). Although OFQUAL identified the possibility for anomalies in grades, they made assurances that the standardisation process would be modelled on historic data available for schools performance and that their equality analysis suggested, 'the production of grades this year has not been compromised by bias in centres' judgements or by the standardisation model' (OFQUAL, 2020a: 9). Significant problems with A-Levels were foreshadowed by the announcement of Scottish exam results on the 4 August. Using a similar model of Centre Assessed Grades and standardisation by the Scottish Qualifications Association many pupils felt their individual results were unfairly downgraded and within one week the Scottish Education Secretary, John Swinney, announced the reinstatement of all downgraded results (BBC, 2020). The announcement of A Level results in England saw a similar pattern of anomalies caused by the standardisation process followed by an announcement from the Secretary of State for Education, Gavin Williamson, that teacher assessed grades would be reinstated (DfE, 2020d).

The detailed technical account of the algorithm used by OFQUAL to standardise Centre Assessed Grades and the pupil rankings provided by schools was released on A Level results day (OFQUAL, 2020b). OFQUAL had trialled 11 approaches to standardisation before settling on the Direct Centre Performance (DCP) model which, '... works by predicting the distribution of grades for each individual school or college. That prediction is based on the historical performance of the school or college in that subject taking into account any changes in the prior attainment of candidates entering this year compared to previous years. This was fine-tuned to take account of known issues such as centres with small cohorts of students, small-entry subjects, and tiered subjects' (2020b:7). OFQUAL stated that in order to, 'understand the impact of potential advantage or disadvantage across different demographic and socio-economic groups we have also performed an equalities analysis of calculated grades. The analyses show no evidence that this year's process of awarding grades has introduced bias' (2020b: 8). However, mirroring the earlier Scottish experience, the 
publication of A Level results led to immediate accusations of unfairness as it became clear that $39 \%$ of Centre Assessed Grades were downgraded; of those downgraded poorer pupils, pupils from marginalised backgrounds, and pupils from state schools were most likely to have been downgraded; whilst more affluent pupils living in wealthier areas and pupils attending independent fee paying schools were less likely to have their grades downgraded (Adams and McIntyre, 2020).

The announcement that pupils' Centre Assessed Grades would be reinstated occurred on $17^{\text {th }}$ August, 5 days after A Level results and the technical detail of the standardisation process were announced. This resulted in various knock-on affects including the need for universities to revisit offers of places where grades changed and the lifting of a government cap on student numbers that was no longer tenable in the face of earlier confusion (Weale and Stewart, 2020). Despite apparently addressing the clear examples of unfairness in the $2020 \mathrm{~A}$ Level results many anomalies remained unaddressed including evidence that pupils from independent fee-paying schools still appeared to have benefited significantly from higher awards of A and A* grades compared to pupils at state schools (Lee, 2020).

\section{Methods}

The research was conducted between April and August 2020, following the official announcements of school closures and cancellation of examinations, but prior to the release of A Level results. A total of 583 A Level students participated in a survey questionnaire widely advertised across social media including Twitter, Facebook and message boards on sites such as Mumsnet and the Student Room. In order to broaden the reach of the research further, links were sent to a range of contacts including schools and special interest groups (e.g. we contacted groups representing Gypsies and Travellers and asked for their help in promoting the survey; and similarly, in order to ensure the representation of independent feepaying schools we approached individual schools requesting they circulate the survey details to their pupils). In addition to the survey we conducted 53 Skype interviews. Ethical clearance was obtained from the University of Birmingham and students were assured of confidentiality and anonymity. A second survey was also distributed via social media the day after A Level results were released (14 ${ }^{\text {th }}$ August 2020) to explore students' views on their results. This report focuses on the findings of the first survey and interviews. 


\section{Survey Findings}

\section{The sample}

The survey was conducted with a broad range of respondents:

- Ethnicity: 59\% White; 18\% Asian; 8\% Mixed Heritage; 7\% Black; 4\% Other

- Gender: 63\% Female; 34\% Male

- Type of School: 68\% State School; 17\% Independent (fee paying)

\section{Satisfaction}

Key initial findings from the survey data include an early analysis of how satisfied pupils were with how their school managed the crisis. These suggest a stark range of pre-existing inequalities have been mirrored since lockdown began and were likely to affect final A Level grades:

- $82 \%$ of White pupils were satisfied with how their school managed the crisis compared to $67 \%$ of Black pupils and only $42 \%$ of Asian pupils feeling similarly satisfied.

- $71 \%$ of girls were satisfied compared to $63 \%$ of boys.

- Whilst $81 \%$ of pupils from fee-paying independent schools were satisfied with how their school managed the crisis only $67 \%$ of pupils in state comprehensive schools were satisfied.

\section{Unfairness}

Perhaps the most striking finding was that only $21 \%$ of students taking the survey suggested they were happy exams were cancelled. More than twice this number (46\%) would have preferred to sit their exams and $33 \%$ of students were undecided. A recurrent theme for many students was their concern about discrepancies between mock exam results and classroom work with 'real exams',

I'm worried that I'm going to be so disadvantaged. I did badly in my mocks, I just didn't work because I knew it wasn't the real thing. I've been working flat out until the day we were told because I knew I could do it for the real exam. It's just not fair. 
Many students also raised concerns their ethnicity could influence how teachers assessed their work. One Black student suggested,

Some of my teachers seem biased. Not badly, but enough to count. They always think the Black boys are trouble. I feel so nervous for the results because even though my course work was good, my mocks were bad - how is that going to be assessed? I haven't had great relationships with my teachers to be fair so they will down grade me.

Another student, an Irish Traveller student said,

We're Travellers. The school doesn't think much of us. This should be my chance at university but maybe it won't happen now. If I mess up an exam I know that's down to me. If a teacher says I'm no good then that is always unfair.

An Indian student said,

My teachers don't think I can do that well, they've predicted me down to AAB but I know I can get 2 A stars, it's what I've been working towards since year 9. I've been getting straight As and now they think I can only get a B-it's just not fair. They also have their favourites, we can all see that - those students who they think should do well, are not those who necessarily will do well.

\section{Understanding the new processes for awarding A Level grades}

Another clear finding from the research was that students' understandings of the new processes involved in assessing their final A Level grades are exceptionally high. In addition to taking advice from teachers and schools many students have independently sought out further information, often from media sites such as the BBC (British Broadcasting Corporation). Consequently, in addition to understanding the specific processes for assessing A Level grades this year they are also well-informed about areas of concern and unfairness including evidence of teacher bias around race and class and variations in school strategies for submitting student work and grades. This was evidenced in the contrasting accounts of students; one for example saying, 
My school has been excellent in letting us know what is happening and we have had continued support and work throughout up to the deadline.

Whilst a student at another school described how,

We didn't get any help, it all just stopped and I was left wondering what was going to happen. I think it means I won't do as well because the teachers just stopped. All the teaching just ended.

One student at an independent, fee-paying school even went as far as to suggest schools were deliberately 'gaming the crisis' and suggested,

Independent schools can sway the system, they want their students to go to good universities so they look good so they will give higher grades. It's rife with academic abuse.

\section{Support and mental health}

Beyond their academic work many students felt they could have been better supported by schools. In particular they highlighted the stress and anxiety of isolation and the uncertainty the sudden lockdown caused. One student discussed her concerns about her mental health,

I suffered a lot because I felt really isolated, I couldn't see my friends and I just can't work at home. This has affected me mentally, it's not just the A Level grades but how I think I will cope by not having my last year - with my mates, my prom. It makes me very anxious.

For many students there was a fear that not only had they been disadvantaged in the short term but also that Covid-19 would have longer term effects on their lives,

I kind of think we're going to be known as the 'covid-19 generation' people are always going to judge us on that - saying oh you didn't take the exams so you're not deserving of the grades. That will have a long term impact on me - on my self-esteem if that's how I'm going to be judged. 


\section{Interview findings}

Preliminary analysis from the interviews broadly mirrored the survey findings, in addition many students raised the following issues;

- The majority recognised the unfairness of the current situation and felt they would be identified and labelled the 'Covid-19 generation'; a cohort of students who did not sit their exams and were awarded estimated grades.

- The majority of students had not changed their plans, all who had applied for university were still keen to go.

- Many students were concerned about the long-term impact on their mental health.

\section{Conclusions}

This report represents an early analysis of some of the broader themes that emerged from the research and will be supplemented in the future by a more comprehensive analysis of the data. Following the widespread concerns of unfairness associated with the 2020 A Level examinations and the subsequent U-turn of the DfE and OFQUAL on Centre Assessed Grades, the author's felt it was useful to highlight the experiences of students. Two findings in particular emerged from students' accounts.

Firstly students from all different backgrounds and different types of schools demonstrated high levels of awareness of the processes by which their exam results would be awarded and also of inequalities built into that process. They highlighted very explicit concerns about how A Level results would be skewed in favour of independent fee-paying schools and how students from ethnic minorities and less affluent areas were likely to be disadvantaged in the process. In this respect many students appeared better able to predict the likely problems of the OFQUAL standardisation process than either the DfE or OFQUAL itself.

Secondly, and allied to the previous finding, students identified the significance of unfairness within their individual experience of taking examinations. Whilst the standardisation process was designed to produce results that collectively mirrored school's past performance and could therefore be described as being collectively fair; the process clearly placed little or no 
value on individual students' experiences. Consequently many students received results they understood to be unfair. To reiterate, students from all types of school and from all backgrounds, consistently identified how exam results would be awarded on an unfair basis reflecting broader structural inequalities within education. 


\section{References}

Adams, R and McIntyre, N (2020) 'England A Level grades downgrades hit pupils from disadvantaged areas hardest'. The Guardian 13 August 2020

https://www.theguardian.com/education/2020/aug/13/england-a-level-downgrades-hit-pupilsfrom-disadvantaged-areas-hardest accessed: 07.09.20

Anders, J., Dilnot, C., Macmillan, L and Wyness, G (2020) Grade Expectations: how well can we predict future grades based on past performance? London: UCL, Centre for Educational Policy and Equalising Opportunity.

BBC (British Broadcasting Corporation) (2020) Scottish pupils have results upgraded in uturn over SQA exams. https://www.bbc.co.uk/news/av/uk-scotland-53742251 accessed: 07.09.20.

Bhopal, K., Myers, M and Pitkin, C (2020) Transitions from higher education: race, class and gender. University of Birmingham, Research report.

DfE (Department for Education) (2020a) Schools, colleges and early years settings to close. https://www.gov.uk/government/news/schools-colleges-and-early-years-settings-to-close accessed: 07.09.20

DfE (Department for Education) (2020b) Further details on exams and grades announced. https://www.gov.uk/government/news/further-details-on-exams-and-grades-announced accessed: 07.09.20

DfE (Department for Education) (2020c) Taking exams during the coronavirus (COVID-19) outbreak. https://www.gov.uk/government/publications/coronavirus-covid-19-cancellationof-gcses-as-and-a-levels-in-2020/coronavirus-covid-19-cancellation-of-gcses-as-and-a-levelsin-2020 accessed: 07.09.20

DfE (Department for Education) (2020d) GCSE and A Level students to receive centre assessment grades. https://www.gov.uk/government/news/gcse-and-a-level-students-toreceive-centre-assessment-grades accessed: 07.09.20

Everet, N and Papageorgiou, J (2011) Investigating the Accuracy of Predicted A Level Grades as part of 2009 UCAS Admission Process. London: BIS.

HoC (House of Commons) (2020) Getting the grades they've earned Covid-19: the cancellation of exams and 'calculated' grades HC 617. London: House of Commons.

Lee, G (2020) Channel 4 News Factcheck: Did England exam system favour private schools? Channel 4 News https://www.channel4.com/news/factcheck/factcheck-did-england-examsystem-favour-private-schools accessed: 07.09.20

Murphy, R, and Wyness, G. (2020) 'Minority Report: the impact of predicted grades on university admissions of disadvantaged group'. Education Economics, 1-18. 
OFQUAL (Office of Qualifications and Examinations Regulation) (2020a) Summer 2020 grades for GCSE, AS and A Level, Extended Project Qualification and Advanced Extension Award in maths Ofqual/20/6662. Coventry: OFQUAL.

OFQUAL (Office of Qualifications and Examinations Regulation) (2020b) Awarding GCSE, AS, A Level advanced extension awards and extended project qualifications in summer 2020: interim report. Coventry: OFQUAL.

University and College Admissions Service (UCAS) (2016) Factors associated with predicted and achieved A Level attainment. Gloucestershire: UCAS.

Weale, S and Batty, D (19 March 2020) 'Fears that cancelling exams will hit black and poor pupils worst.' The Guardian https://www.theguardian.com/world/2020/mar/19/fears-thatcancelling-exams-will-hit-black-and-poor-pupils-worst accessed: 07.09.20

Weale, S and Stewart, S (2020) 'A Levels and GCSE results in England to be based on teacher assessed grades in U-turn'. The Guardian 17 August 2020 https://www.theguardian.com/education/2020/aug/17/a-levels-gcse-results-england-basedteacher-assessments-government-u-turn accessed: 07.09.20

Wyness, G (2017) Rules of the game: disadvantaged students and the university admissions process. London: Sutton Trust. 
For further information please contact:

Kalwant Bhopal

Director, Centre for Research in Race \& Education (CRRE)

University of Birmingham

Edgbaston

B15 2TT

UK

K.Bhopal@Bham.ac.uk

Martin Myers

School of Education

University of Nottingham

Nottingham

NG8 1BB

UK

Martin.Myers@Nottingham.ac.uk 